\title{
Prenatal Effects of Plastic Migrants in Commercial Peritoneal Dialysis Solution
}

\author{
Al-ser A. Al-Khatim and Khalid El-Tom Ali ${ }^{1}$ \\ Department of Environmental Sciences, \\ Faculty of Meteorology, Environment and Arid Land Agriculture, \\ King Abdulaziz University, Jeddah, Saudi Arabia and \\ ${ }^{I}$ Department of Biochemistry, Faculty of Medicine, \\ International University of Africa, Khartoum, Sudan
}

\begin{abstract}
Commercial peritoneal dialysis solution (PDS) is widely used in the treatment of uremic patients. This type of PDS is expected to be contaminated with leachable agents originating from the plastic material of the packaging bags. Injection of the solution $(280 \mathrm{ml} / \mathrm{kg}$, i.p) into pregnant MF1 mice was applied to investigate the prenatally-induced adverse effects in their progeny due to such plastic leachables. Daily injection started; from Day 0 of gestation and continued up to delivery. The dose was divided into two equal volumes given at $10 \mathrm{a} . \mathrm{m}$. and 10 p.m. A group of pregnant mice, of 10 animals, was given the PDS of bags stored at room temperature $\left(25^{\circ} \mathrm{C}\right)$. A similar group was given the PDS of bags preheated in a waterbath $\left(50^{\circ} \mathrm{C}\right)$ for overnight. A third group was given a prepared control PDS from the same chemicals, stored in glass bottles from the manufacturing companies, according to the concentrations specified on the PDS bag. After weaning (one-month age), the offspring of each group were subjected to a battery of biochemical tests. The results showed that commercial PDS has induced the following significant effects in the offspring: elevation in the activity of blood alkaline phosphatase (ALP), increase in the blood concentration of the nonprotein nitrogenous (NPN) compounds (urea, creatinine and uric acid), and total blood cholesterol. There were also a higher percentage of stillbirths in the progeny of treated mothers. Most of the previous effects were clearly pronounced in the offspring of mothers treated with preheated-bag PDS.
\end{abstract}

It was concluded that the plastic bags of the investigated PDS were leachable, and the chemical agents originating from the plastic material of these bags were toxic to the mice under study. The PDS concentration of these leachables may increase with time and storage of 
the bags under hot weathers. Based on the results of this study, strict control of storage temperature is recommended to minimize the leachability of these PDS bags and thus lessening the health problems that may arise in patients undergoing long-term peritoneal dialysis.

Keywords: Peritoneal dialysis solution (PDS); prenatal effects; mice; plastic bags; leachables.

\section{Introduction}

Plastic bags are used to package peritoneal dialysis solution (PDS), which is widely applied in the treatment of uremia and patients with acute renal failure (Rubenstein and Wayne, 2003). In this technique PDS is infused into the peritoneal cavity of the patient via a catheter by gravity flow. The PDS is left there for about 60 minutes (equilibration period) after which the dialysate is drained off by gravity flow. This process is repeated hourly for 36 to 48 hours until the metabolic wastes are removed. This might require six to ten 2-liter-bag exchanges in a stable adult patient or more than 30 bag exchanges in severely catabolic patients (Daugirdas et al., 2006).

However, the contamination of this PDS type by chemical agents that leach from the plastic material of the bag has been pointed out by some scientists (Carozzi et al., 1993; Sevela et al., 1996 and Mettang et al., 1999). Plastic items, used in medical and paramedical fields, have long been known of this phenomenon of plastic additive migration (Lyman, 1999 and Rais-Bahrami et al., 2004). Additives in plastics are various chemicals blended with the parent polymer to produce the final product. Such additives include plasticizers, stablizers, antioxidants, colorants, and flame retardants. The addition of these chemical agents during the industrial process is meant to obtain the physical and mechanical properties found in plastics (Harper, 2006). Moreover, the presence of unpolymerized molecules (monomers, dimers, oligomers) and traces of chemicals, such as ethylene oxide, applied to sterlize plastic items, might pose another health threat beside the problem of plastic additive migration (Castle et al.,1996 and Lyman and Rowland, 2007).

No doubt, any contamination due to leachable agents can lead to adverse effects in uremic patients undergoing long-term peritoneal dialysis.

In this research a commercial PDS has been investigated to assess the possible toxic effects in the offspring of mice, prenatally treated with the solution. 


\section{Materials and Methods}

\section{Animals}

Three-month old virgin female and adult male MF1 mice, weighing between 25 and $30 \mathrm{~g}$, were used for this research. These mice were obtained from the animal house of King Fahad Medical Research Center, Faculty of Medicine, King Abdulaziz University. One male and two females were housed together in individual macrolone cages $(27 \times 21 \times 14 \mathrm{~cm})$, with sawdust bedding, and were provided with commercial laboratory chow and fresh tap water ad libitum. The colony room has been on a $12 \mathrm{hr}$ light and $12 \mathrm{hr}$ dark lighting cycle and the temperature was controlled at $26 \pm 2^{\circ} \mathrm{C}$, with full ventilation throughout the experiments. Females were mixed with males at 7 PM, and the next morning females were observed for vaginal plug, as a sign of copulation. The day on which vaginal plug was observed was counted as Day 0 of the gestation period. Each mated female was placed in a private cage up to delivery, under the same conditions.

\section{Materials}

Fresh, sterile, and pyrogen-free PDS packaged in plastic bags, was used. Samples of this PDS were kindly supplied by the Peritoneal Dialysis Unit of a Sudanese hospital in Khartoum, where the bags were stored at room temperature $\left(25^{\circ} \mathrm{C}\right)$. The control PDS was prepared in the laboratory with the same recipe described for this commercial PDS on the 2-L-bag, using highly pure chemicals ( $>99 \%$ ) stored in glass bottles.

\section{Preparation of the Control PDS}

The chemicals required to prepare the control PDS were kindly supplied by the Biochemistry Department, Faculty of Medicine, and the Chemistry Department, Faculty of Science, King Abdulaziz University, Jeddah, Saudi Arabia.

According to the recipe printed on the commercial PDS bag, the 2-liter solution contained the following ingredients with their corresponding quantities: sodium chloride $(\mathrm{NaCl}), 11.52 \mathrm{~g}$; potassium chloride $(\mathrm{KCl}), 0.3$ g; calcium chloride, dihydrate $\left(\mathrm{CaCl}_{2} .2 \mathrm{H}_{2} \mathrm{O}\right), 0.52 \mathrm{~g}$; magnesium chloride, hexahydrate $\left(\mathrm{MgCl}_{2} \cdot 6 \mathrm{H}_{2} \mathrm{O}\right), 0.152 \mathrm{~g}$; sodium lactate $\left(\mathrm{CH}_{3} \mathrm{CHOHCOONa}\right)$, $8.4 \mathrm{~g}$; and D-glucose, monohydrate $\left(\mathrm{C}_{6} \mathrm{H}_{12} \mathrm{O}_{6} \cdot \mathrm{H}_{2} \mathrm{O}\right), 30.0 \mathrm{~g}$.

These chemicals were weighed accurately and dissolved completely in two liters of sterile deionized water. The resulting solution was stored in sterile glass bottles with glass stoppers. 
The commercial PDS bags and the control PDS were kept in the fridge $\left(4^{\circ} \mathrm{C}\right)$, and the bags were retained in their intact condition. Samples for daily injection were drawn from the PDS bag with a sterile syringe. Samples were collected daily in 100-ml glass flasks (with glass stoppers) and sterilization of the samples was performed, using the autoclave (15 min., $\left.121^{\circ} \mathrm{C}\right)$. Control PDS samples were taken from the stock and placed in similar flasks, sterilized in the same way, given to control animals simultaneously, under the same conditions.

\section{Animal Treatments}

The commercial and the control PDSs were injected into the mice intraperitoneally (i.p.) at a dose of $280 \mathrm{ml} / \mathrm{Kg}$ (given in two equal volumes at $10 \mathrm{am}$. and $10 \mathrm{pm}$.) according to the following protocol:

Two groups of pregnant mice, 10 animals each, were designated as " $\mathrm{T}_{1}$ " and " $\mathrm{T}_{2}$ " and injected with the commercial PDS: $\mathrm{T}_{1}$ with PDS whose bag was stored at room temperature (in the hospital) and $T_{2}$ with PDS whose bag has been preheated in the waterbath at $50^{\circ} \mathrm{C}$ for overnight in the present study. The control group " $\mathrm{C}$ ", of 10 pregnant animals also, was injected with the control PDS. Injection of all groups started from Day 0 of gestation until delivery. From the first day of delivery, the offspring of the three groups were subjected to various biochemical and hematologic tests.

The selected dose was based on the average amount of PDS infused into the peritoneal cavity of the adult renal failure patient $(70 \mathrm{Kg})$. According to Daugirdas et al. (2006), six to ten 2-L exchanges will remove the usual 24-hour accumulation of metabolic wastes. So, the maximum tolerable daily dose for such patient is 20 liters. Thus, from the equation below, the daily dose applied to any of the pregnant animals was:

$$
(20000 \mathrm{ml} \times \text { wt. }) / 70000 \mathrm{~g}=\mathrm{ml}
$$

Where wt. is the animal weight in $(\mathrm{g})$.

The treatment of animals here may seem different from the situation in the patient, due to the fact that the infused PDS is drained away from the patient's peritoneal cavity after the dwelling time. Sevela et al. (1996) reported that drainage of the solution would not affect the absorption of some of the plastic leachables by the peritoneum. This was clear from their finding that plasticizers were retained and metabolized in the peritoneal 
cavity. Other leachables might behave alike.

Toxic effects in the offspring, due to prenatal treatment of mothers, were assessed using the following parameters:

A. The biochemical profile (Willard and Tvedten, 2003)

(i) Hepatic function

Determined by measuring albumin-globulin ratio (A/G), activity of plasma AST, ALT, and alkaline phosphatase (ALP).

(ii) Renal function

Determined by assaying plasma NPN compounds (urea, creatinine, and uric acid) and electrolytes ( $\mathrm{Na}, \mathrm{K}, \mathrm{P}, \mathrm{Ca}$, and $\mathrm{Cl})$.

(iii) Organ-to-body weight ratios of the liver and kidneys

(iv) Blood lipids

Lipids assayed were plasma total cholesterol, high-density lipoprotein (HDL) cholesterol, and triglycerides.

\section{B. Litter size and stillbirths.}

\section{Methods of Analysis}

Fresh blood samples were drawn from animals by cardiac puncture technique, placed into heparinized vials, and centrifuged to obtain the plasma. Plasma samples were analyzed for liver function tests, kidney function tests, and blood lipids with Hitachi Autoanalyzer, Model 917, Tokyo, Japan.

\section{Statistical Analysis}

One-way analysis of variance (ANOVA) was applied to evaluate data for significant differences between groups. A confidence level of 95\% $(\mathrm{P}<0.05)$ was selected for significance. Statistical analysis was performed using SAS software (SAS Inc., 2000), according to El-Nakhlawy (2010).

\section{Results and Discussion}

The commercial PDS caused significant rises in the activity of plasma ALP and in total blood cholesterol (Table 1 and 3) in group $\mathrm{T}_{2}$ offspring only. There were significant elevations in the NPN compounds in the offspring of both treatment groups (Table 2). 
Table 1. Mean Prenatal effects of commercial peritoneal dialysis solution (PDS), injected daily (i.p.) into pregnant MF1 mice $(280 \mathrm{ml} / \mathrm{kg})$ during the gestation period, on the liver's weight (related to total body weight) and function in the 1-month-old offspring.

\begin{tabular}{|c|c|c|c|c|c|}
\hline Treatment & Liver wt. \% & A/G & ALP, U/L & ALT, U/L & AST, U/L \\
\hline T2 (10) & 5.38 & 1.19 & $615.9^{*}$ & 16.7 & 80.7 \\
\hline T1 (10) & 5.18 & 1.24 & 575.20 & 17.1 & 74.6 \\
\hline C $(10)$ & 5.13 & 1.18 & 574.60 & 16.8 & 77.4 \\
\hline I S.E. & 0.12 & 0.03 & 11.45 & 0.59 & 2.24 \\
\hline L.S.D & 0.35 & 0.09 & 33.19 & 1.71 & 6.47 \\
\hline
\end{tabular}

( ) Number of offspring per group.

T2 Animals treated with PDS from bags preheated overnight in waterbath at $50^{\circ} \mathrm{C}$

T1 Animals treated with PDS from bags stored at room temperature $\left(25^{\circ} \mathrm{C}\right)$.

C Control group, given the plastic-free PDS.

A/G Albumin to globulin ratio.

ALP Alkaline phosphatase.

ALT Alanine aminotransferase.

AST Aspartate aminotransferase.

$\mathrm{U} / \mathrm{L} \quad$ Unit per liter.

* Significantly different from the control $(\mathrm{P}<0.05)$.

L.S.D. Least significant difference.

Table 2. Mean Prenatal effects of commercial peritoneal dialysis solution (PDS), injected daily (i.p.) into pregnant MF1 mice $(280 \mathrm{ml} / \mathrm{kg})$ during the gestation period, on the Kidneys' weight (related to total body weight) and function in the 1-month-old offspring.

\begin{tabular}{|c|c|c|c|c|c|c|c|c|c|}
\hline Treatment & $\begin{array}{c}\text { Kid. Wt. } \\
\%\end{array}$ & $\begin{array}{c}\text { Urea } \\
\mathrm{mmol} / \mathrm{L}\end{array}$ & $\begin{array}{c}\text { Creat. } \\
\mu \mu \mathrm{mol} / \mathrm{L}\end{array}$ & $\begin{array}{c}\text { Uric acid } \\
\mu \mu \mathrm{mol} / \mathrm{L}\end{array}$ & $\begin{array}{c}\mathrm{Na} \\
\mathrm{mmol} / \mathrm{L}\end{array}$ & $\begin{array}{c}\mathrm{K} \\
\mathrm{mmol} / \mathrm{L}\end{array}$ & $\begin{array}{c}\mathrm{P} \\
\mathrm{mmol} / \mathrm{L}\end{array}$ & $\begin{array}{c}\mathrm{Ca} \\
\mathrm{mmol} / \mathrm{L}\end{array}$ & $\begin{array}{c}\mathrm{Cl} \\
\mathrm{mmol} / \mathrm{L}\end{array}$ \\
\hline $\mathrm{T}_{2}(10)$ & 1.15 & $6.54^{*}$ & $33.4^{*}$ & $41.2^{*}$ & 140.1 & 4.17 & 2.74 & 2.44 & 106.7 \\
\hline $\mathrm{T}_{1}(10)$ & 1.14 & 6.37 & $34.1^{*}$ & $40.7^{*}$ & 141.7 & 4.12 & 2.81 & 2.54 & 108.2 \\
\hline $\mathrm{C}(10)$ & 1.24 & 6.13 & 31.9 & 35.4 & 142.2 & 4.21 & 2.72 & 2.50 & 107.7 \\
\hline 土 S.E. & 0.04 & 0.09 & 0.45 & 0.59 & 0.92 & 0.06 & 0.05 & 0.04 & 0.91 \\
\hline L.S.D & 0.12 & 0.26 & 1.30 & 1.71 & 2.67 & 0.17 & 0.14 & 0.12 & 2.64 \\
\hline
\end{tabular}

( ) Number of offspring per group.

T2 Animals treated with PDS from bags preheated overnight in waterbath at $50^{\circ} \mathrm{C}$.

T1 Animals treated with PDS from bags stored at room temperature $\left(25^{\circ} \mathrm{C}\right)$.

C Control group, given the plastic-free PDS.

* Significantly different from the control $(\mathrm{P}<0.05)$.

L.S.D. Least significant difference.

Table 3. Mean prenatal effects of commercial peritoneal dialysis solution (PDS), injected daily i.p.) into pregnant MF1 mice $(280 \mathrm{ml} / \mathrm{kg})$ during the gestation period, on the concentration of blood lipids in the 1-month-old offspring.

\begin{tabular}{|c|c|c|c|}
\hline Treatment & T. Cholesterol mmol/L & HDL Cholesterol mmol/L & Triglycerides $\mathrm{mmol} / \mathrm{L}$ \\
\hline T2 $(10)$ & $3.48^{*}$ & 2.42 & 2.05 \\
\hline T1 (10) & 3.09 & 2.29 & 1.71 \\
\hline C (10) & 3.13 & 2.28 & 1.86 \\
\hline 土 S.E. & 0.07 & 0.05 & 0.17 \\
\hline L.S.D & 0.20 & - & 0.49 \\
\hline
\end{tabular}

( ) Number of offspring per group.

T2 Animals treated with PDS from bags preheated overnight in waterbath at $50^{\circ} \mathrm{C}$.

T1 Animals treated with PDS from bags stored at room temperature $\left(25^{\circ} \mathrm{C}\right)$.

C Control group, given the plastic-free PDS.

HDL High-density lipoprotein.

* $\quad$ Significantly different from the control $(\mathrm{P}<0.05)$.

L.S.D. Least significant difference. 
Although the PDS had no effect on the litter size, as indicated by Table 4, the percentage of stillbirths was considerably higher in the treatment groups in contrast to the control.

Table 4. Mean prenatal effects of commercial peritoneal dialysis solution (PDS), injected daily (i.p.) into pregnant MF1 mice $(280 \mathrm{ml} / \mathrm{kg})$ during the gestation period, on the litter's size and percentage of stillbirths.

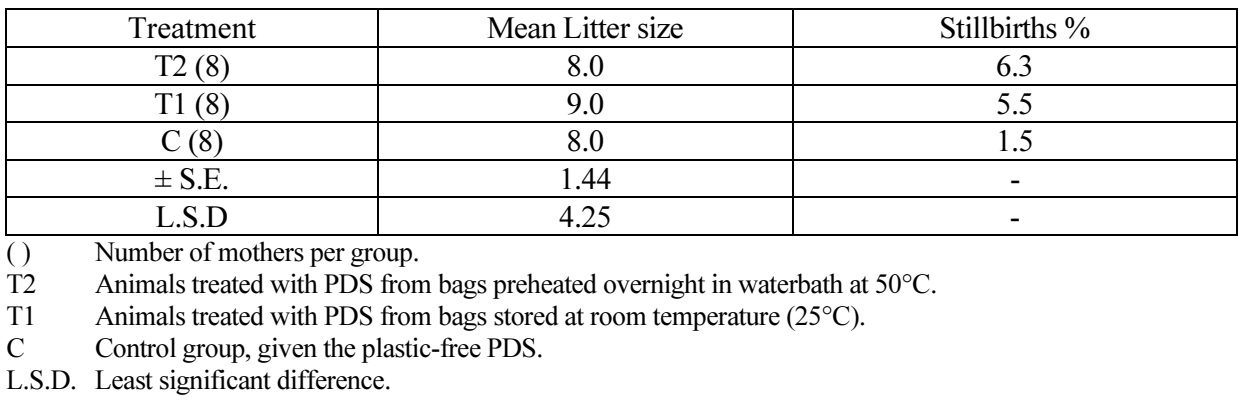

\section{Liver Function}

The liver is the target organ for many xenobiotics, where metabolic and detoxifying processes take place (Rozman and Klaassen, 1996). Stabilizers, like organotin compounds, and plasticizers of phthalic acid esters, used widely as additives in plastics, were found to be hepatic tumorigens (Astill et al., 1996 and Wine et al., 1997). Table 1 indicates that elevated temperature seems to enhance the migration of plastic leachables from the PDS bag, leading to the significant rise in ALP activity in the offspring of group $\mathrm{T}_{2}$. This apparently prenatal hepatotoxic effect may indicate that similar migrating plastics additives and/or their metabolites might have crossed the placental barrier to the conceptus.

\section{Kidney function}

The kidney is the important organ through which most of the metabolic waste products are excreted. The filtration units in the kidney are the nephrons_(Hall, 2005). Because of the high blood flow through the kidney, any drug or chemical in the systemic circulation will be delivered in relatively high amounts to this organ and might become a nephrotoxicant to any element in the nephron (Hewitt et al.,1991). The glomerular capsule has a membrane highly permeable to metabolic wastes (Hall, 2005). The glomerular capillaries or membrane can be damaged by xenobiotics. Some of the renal function tests that are normally performed in the laboratory may reveal primarily disturbances in glomerular filtration, and others reflect dysfunction of the tubules, but damage is seldom confined solely to a 
particular portion of the nephron (Hewitt et al.,1991). The renal function tests run in this study indicate that the nephronal function might have been affected directly and/or indirectly by the leaching agents from the PDS bags, since all blood NPN compounds assayed were significantly elevated in the offspring of treated mothers (Table 2). These results agree with the findings of Arcadi et al. (1998) who reported histological damage in kidneys of rat litter due to prenatal treatment of mothers with the phthalic acid ester plasticizer bis(2-ethyl-hexyl) phthalate.

\section{Blood Lipids}

The result obtained for total blood cholesterol (Table 3) agrees with the finding of Latendresse et al. (1995) who reported significant elevation of this lipid in rats treated with tri-aryl phosphate, the additive used as flame retardant and plasticizer in the manufacture of plastics. This elevation in cholesterol should be correlated with the rise of alkaline phosphatase activity reported previously, which might have arisen from cholestasis. This value, reported for $T_{2}$ group, shows clearly that elevated temperature has enhanced the leachability of the plastic material of the PDS bags.

\section{Stillbirths}

The aforementioned outcomes of the studied PDS may confirm placental transfer of leachable additives, unpolymerized molecules, and/or metabolites that might be formed from these agents, and their impact upon the fetuses. Alkhatim (2005) reported significant ratios of stillbirths and preterm deliveries when he treated mice with high-density polyethylene (HDPE) and silicone rubber (SR) extracts, respectively, during the gestation period. The higher percentage of stillbirths shown in Table 4 , for both $T_{1}$ and $\mathrm{T}_{2}$ groups indicates this in-utero effect of plastic migrants.

According to Rozman and Klaassen (1996), several pregnancy-related physiological alterations favor increased absorption and influence the distribution of xenobiotics, e.g. the increase in total body fat and the drop in the amount of plasma binding proteins. Also, many foreign compounds can cross the placenta, and passive diffusion appears to be the mechanism of their migration through this organ. The more lipid-soluble substances traverse easily and attain the maternal-fetal equilibrium more rapidly. Depending on these facts, one would expect that the placenta itself might have been vulnerable to chemical insult. Many chemicals in the environment have been associated with reproductive dysfunction and 
disorders in females. These chemicals include plastic additives and monomers (Thomas, J.A., 1991 and Davis and Bradlow 1995). The incidence of higher percentages of stilbirths (Table 6) might be attributed to diminished production of the placental hormone estriol in late pregnancy, the formation of which reflects a number of fetoplacental functions (Granner, 1996). Al-Hachim and Al-Khatim (1997) and Ema et al. (1996) showed that plasticizers and unpolymerized monomers and/or their metabolites might be responsible for causing intrauterine malformations, fetal death, and miscarriage. Our results apparently agree with the findings of these researchers.

\section{Conclusions}

This study shows clearly that the plastic bags of the investigated PDS are leachable. The findings shown in this research indicate the toxicity of the leached compounds and/or their metabolites. Although elevated temperatures, to which the bags may be exposed during storage, may enhance the migration of additives from the plastic material of the bags, this migration can occur even at room temperature (under which the PDS bags were stored). It is noted that the effects of PDS whose bags were stored at room temperature $\left(25^{\circ} \mathrm{C}\right)$ were less than those induced by the preheated-bag PDS. This supports the idea that elevated temperature enhances plastic leachability. The migrating agents and/or their metabolites might have passed the placental barrier to the conceptus.

The various toxic effects induced in the mice progeny due to prenatal treatment of mothers may indicate the diversity of the leached agents. Such effects can be extrapolated in patients using this type of PDS (e.g. renal failure patients). The use of freshly-prepared PDS and cool storage of the solution would minimize these adverse effects. Local preparation of the solution, instead of importing it, should also be encouraged and supported by health authorities.

\section{References}

Al-Hachim, G.M. and Al-Khatim, A.A. (1997) Prenatal effects of aqueous plastic extract on offspring. Fetal Diagnosis and Therapy, 12: 28-31.

Alkhatim, A.A. (2005) Effects of plastics extract migrants on reproduction in experimental mice. Ph.D. thesis, University of Gezira, Faculty of Medicine, Wad Medani, Sudan.

Arcadi, F.A., Costa, C., Imperatore, C., Marchese, A., Rapisarda, A., Salemi, M., Trimarchi, G.R. and Costa, G. (1998) Oral toxicity of bis(2-ethylhexyl) phthalate during 
pregnancy and suckling in the Long-Evans rat. Food and Chemical Toxicology, 36(11): 963-970.

Astill, B.D., Gingell, R., Guest, D., Hellwig, J., Hodson, J.R., Kuettler,K., Mellert, W., Murphy, S.R., Sielken, R.L. Jr. and Tyler,T.R. (1996) Oncogenicity testing of 2ethylhexanol in Fischer 344 rats and B6C3F1 mice. Fundam. Appl. Toxicol. 31(1): 29-41.

Carozzi, S., Nasini, M.G., Schelotto, C., Caviglia, P.M., Santoni, O. and Pietrucci, A. (1993) A biocompatibility study on peritoneal dialysis solution bags for CAPD. Adv. Perit. Dial., 9: $138-42$.

Castle, L., Price, D. and Dawkins, J.V. (1996) Oligomers in plastics packaging. Part 1: Migration tests for vinyl chloride tetramer. Food Additives and Contaminants, 13(3): $307-$ 314.

Daugirdas, J.T., Blake, P.G. and Ing, T.S. (2006) Handbook of Dialysis, 4th ed., Lippincott Williams \& Wilkins, New York pp 774.

Davis, D.L. and Bradlow, H.L. (1995) Can environmental estrogens cause breast cancer? Sci. Am. 273(4): 166-71.

El-Nakhlawy, F.S. (2010). Experimental Design and analysis in Scientific Research. Sci. Pub. Center, KAU, Jeddah, Saudi Arabia.

Ema, M., Iwase, T., Iwase, Y., Ohyama, N. and Ogawa, Y. (1996) Change of embroyotoxic susceptibility to di-n-butyltin dichloride in cultured rat embryos. Arch. Toxicol., 70(11): $742-8$.

Granner, D.K. (1996) Hormones of the gonads. In: Murray, K., Granner, D.K., Mayes, P.A., Rodwell, V.W. (eds.): Harper's Biochemistry, 24th ed., Prentice-Hall International Inc., London, pp.566-580.

Hall, J. (2005) Guyton and Hall Medical Physiology, $11^{\text {th }}$ ed., W.B. Saunders Company, Philadelphia. pp. 1576.

Harper, C.A. (2006) Handbook of plastics technologies: the complete guide to properties and performance. $2^{\text {nd }}$ ed., McGraw-Hill, New York, pp. 900.

Hewitt, W.R., Goldstein, R.S. and Hook, J.B. (1991) Toxic responses of the kidneys. In: Klaassen, C.D., Amdur, M.D., Doull, J. (eds.), Casarett and Doull's Toxicology. The Basic Science of Poisons, $4^{\text {th }}$ ed., Pergamon, New York, pp. 354-379.

Latendresse, J.R., Brooks, C.L. and Capen, C.C. (1995) Toxic effects of butylated triphenyl phosphate-based hydraulic fluid and tricresyl phosphate in female F344 rats. Vet. Pathol., 32(4): 394-402.

Lyman, D.J. (1999) Polymers. In Von Recum AF (ed): Handbook of Biomaterials Evaluation: Scientific Technical and Clinical Testing of Implant Materials, $2^{\text {nd }}$ ed.. CRC Press, New York, pp. 37-50.

Lyman, D.J. and Rowland, S.M. (2007) Biomedical Materials. In: Mark, H.F. (ed.), Encyclopedia of Polymer Science and Technology, $3^{\text {rd }}$ ed., Wiley-Interscience, New York.

Mettang, T., Alscher, D.M., Pauli-Magnus, C., Dunst, R., Kuhlmann, U. and Rettenmeier A.W. (1999) Phthalic acid is the main metabolite of the plasticizer di(2-ethylhexyl) phthalate in peritoneal dialysis patients, Adv Perit Dial., 15: 229-33.

Rais-Bahrami, K., Nunez, S., Revenis, M.E., Luban, N.L. and Short, B.L. (2004) follow-up study of adolescents exposed to di(2-Ethylhexyl) phthalate (DEHP) as neonates on extracorporeal membrane oxygenation (ECMO) support, Environmental Health Perspectives, 112(13): 1339-1340.

Rozman, K.K. and Klaassen, C.D. (1996) Distribution, excretion, and absorption of toxicants. In: Klaassen, C.D., Amdur, M.D. and Doull, J. (eds.), Casarett and Doull's Toxicology. The Basic Science of Poisons. $5^{\text {th }}$ ed, New York, Macmillan Publishing Company, pp. 91-109.

Rubenstein, D. and Wayne, D. (2003) Lecture Notes on Clinical Medicine. 6th ed., Blackwell Scientific Publications, London, Edinburgh, and Boston, pp. 360.

SAS (2000). SAS Institute Inc., Cary, NC, USA. 
Sevela, K., Gajduskova, V., Havlat, F., Havrankova, V. and Jarosova, A. (1996) Phthalic acid esters in the peritoneal cavity of patients treated with continuous ambulatory peritoneal dialysis. Vnitr. Lek. 42(6): 404-7.

Thomas, J.A. (1991). Chapter 16. Toxic responses of the reproductive system. In: Casarett and Doull's Toxicology. The Basic Science of Poisons, 4th ed. M.O. Amdur, J. Doull and C.D.Klaassen, (eds.), Pergamon Press, New York.

Willard, M. and Tvedten, H. (2003) Small Animal Clinical Diagnosis by Laboratory Methods. Saunders, Texas, pp 448.

Wine, R.N., Li, L.H., Barnes, L.H., Gulati, D.K. and Chapin, R.E. (1997) Reproductive toxicity of di-n-butylphthalate in a continuous breeding protocol in sprague-dawley rats. Environmental Health Perspectives, 105(1): 102-107. 
التأثيرات القبولادية لمرتشحات البلاستيك في محلول الاستصفاء البريتوني التجاري

السر عبد القادر الخاتم و خالد التوم علي' قسم العلوم البيئية، كلبة الأرصاد والبيئة وزراعة الدناطق الجافة، جامعة الدلك عبدالعزيز، جدة - المملكة العربية السعودية ' قسم الكيمياء الحيوية والتغذية، كلية الطب، جامعة الجزيرة، ود مدنس، السودان

المستخلص. يستخدم المحلول التجاري للاستصفاء البريتوني (PDS) على نطاق واسع في معالجة مرضى الفتل الكلوي. ومن المحتمل أن يحتوي هذا المحلول على مركبات ملوّتثة مرتثحة من مادة البلاستيك منكي

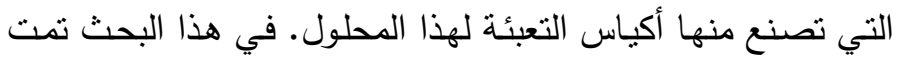

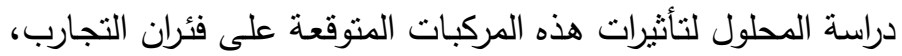

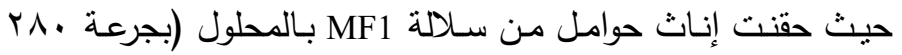
مللتر/ كجم، في الغشـاء البريتوني) بهدف التعرف على التأثنرات

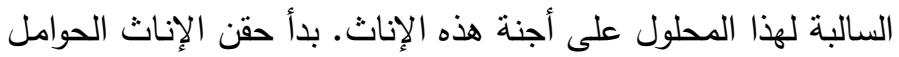

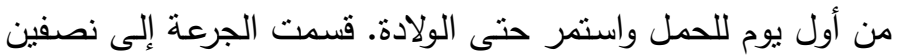

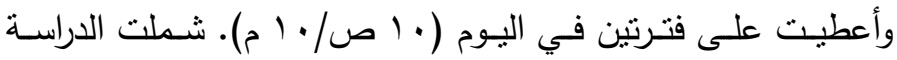

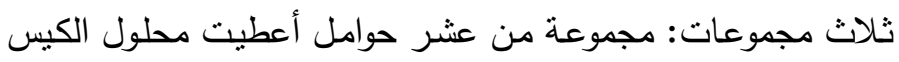

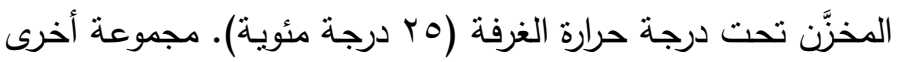

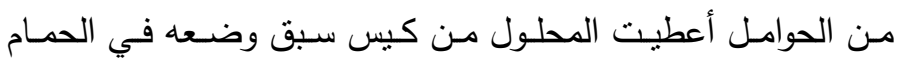

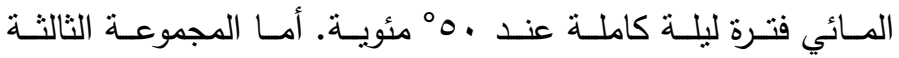

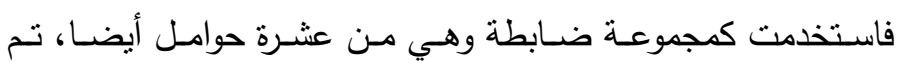
إعطاؤهـا المحلـول المضـر في المعهـل بـنفس مواصـفات وتركيز 
مكونات محلول الـ PDS، وذلك من مواد كيميائية عالية النقاوة ومعبئة في حاويات زجاجية فقط كما وضع هذا المحلول في حاوية زجاجية

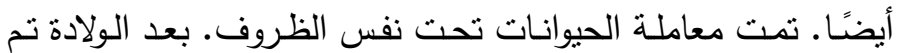

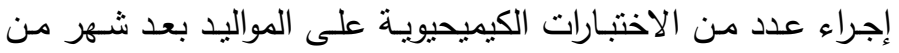

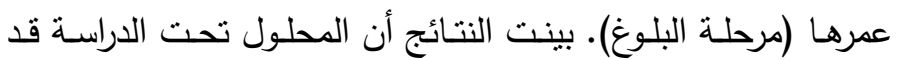

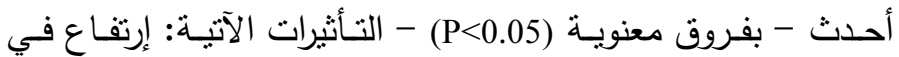

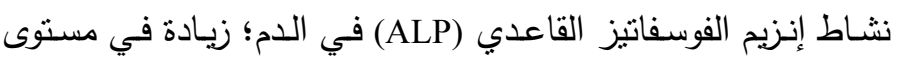

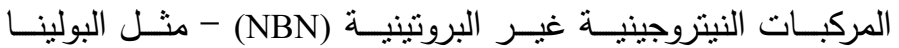
والكرياتنينين وحمض البوليك؛ وزيادة في مستوى الكولستيرول الكلي لئي

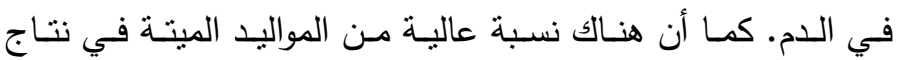

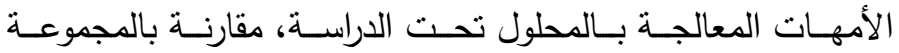
الضابطة. كانت التأثنرات للمحلول المعرّض للحرارة أكثر وضوحًا.

دلت هذه الدراسـة على أن أكياس المحلول تحت الدراسة قابلة

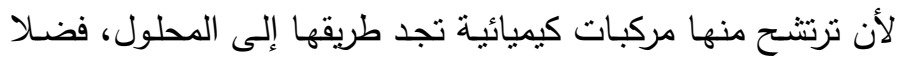

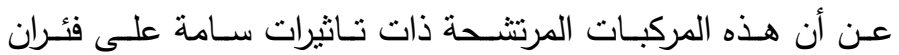
التجارب. كمـا أن تركيز هذه المركبـات قد يزيــ مـع مـدة التخزين

$$
\text { وارتفاع درجة الحرارة. }
$$

توصي الدراسة - بناءً على النتائج المتحصل عليها - بتطبيق

نظام صارم بضبط درجة الحرارة التي يتم تخزين هذه الأكياس تحتها، وذللك لتقليل التاثيرات السامة على المرضى الذين يخضعون لعملية الاستصفاء البريتوني، لا سيما لفترات طويلة. الكلمات الدالة: محلول الاستصفاء البريتوني (PDS)؛ فئران التجارب؛ أكياس البلاستيك؛ المرتشحات الكيميائية. 